\title{
Social Accountability in the Extractive Industries: A Review of the Ethiopian Experience
}

\author{
Fenta Mandefro, $\mathbf{P h D}^{1}$
}

\begin{abstract}
Resource rich countries of Africa, except few, have not succeeded in reducing poverty and improving the living conditions of the majority of poor citizens. Lack of a proper social accountability system and practice are among the major factors contributing to the problem. As a result, social accountability has received attention from policy makers, policy researchers and donors. This research, based on desk reviews, tries to discuss the concepts, actors and mechanisms of social accountability and then reflects on the Ethiopian experience in general and on legal regimes for social accountability in the extractive industries in particular. Assessment revealed that the concept of social accountability is pretty new to Ethiopia. Issues and concerns of social accountability constitute important components of human rights. In light of this, the legal regimes for the extractive industry in Ethiopia have provided basic legal and regulatory frameworks for social accountability. Nonetheless, most of the legal and regulatory provisions are not sufficient to fully promote and ensure social accountability. The laws have provided discretionary powers to public agencies to decide on citizens' rights. Local peoples' objections to any project to be implemented on their land and territories, or to any proposed displacement by extractive project, or any disagreement with a project owner on the amount of compensation is not binding. This is against the principles of social accountability in the extractive industries. Effective social accountability depends on the proper functioning of the supply and demand sides of social accountability. Provision of legal and regulatory frameworks by government to govern decisions and actions of implementing government agencies and private sector actors is not enough. There should be demand from citizens in general and the local people in particular where projects are implemented.
\end{abstract}

Keywords: Social accountability, extractive industries, Ethiopia DOI: https://dx.doi.org/10.4314/ejbe.v6i1.1

\footnotetext{
${ }^{1}$ Assistant Professor, Department of Public Administration and Development Management, College of Business and Economics, Addis Ababa University, E-mail: fenfet@gmail.com
} 
Social Accountability in the Extractive Industries

\section{Introduction}

Resource rich countries of Africa, except few, have not succeeded in reducing poverty and improving the living conditions of the majority of poor citizens. Studies show that extractions of resources have exacerbated poverty in such countries due to displacement of local peoples from their lands, territories and resources on which their livelihoods depend (UNITR, n.d). Lack of a proper social accountability system and practice are among the major factors contributing to the problem. As a result, social accountability has received attention from policy makers, policy researchers and donors. Moreover, local peoples and their advocates are putting pressure on national governments and demanding international organizations, such as the United Nations, to stop the unsustainable and socially irresponsible exploitation of natural resources. This research is part of such initiatives towards improved social accountability of the extractive industries. The research method employed in undertaking this research is purely qualitative. Based on desk reviews, the research tries to discuss the concepts, actors and mechanisms of social accountability and then reflects on the Ethiopian experience in general and on legal regimes for social accountability in the extractive industries in particular. The legal regimes are reviewed in light of the human rights and sustainability principles of social accountability. The principle of social license to operate is a pragmatic approach that requires empirical investigation in areas where extractive industries are operating. Thus, it is not discussed in this paper due to the desk review method the study employed.

\section{Governance of the Extractive Industry: a Prelude}

Governance is a very fluid term which may mean different things unless the context is clearly stated. In the context of a broader public sector, it generally refers to the process and institutions by which authority is exercised in a country. The capacity of governments to manage resources efficiently; formulate, implement and enforce sound policies and regulations; rule of law and respect for institutions that govern political, economic and social interactions; and transparency, accountability and equity in decision-making are key attributes of governance in the public sector (IBRD, 2005).

Governance has gained popularity in the development discourse in general and in Africa's development agenda in particular. This is due to the fact that Africa's development problems have been mainly linked to governance issues (ECA, 2007).

EJBE Vol. 6 No. 1/2016 
Extractive industries remain the economic bedrock for many developing countries, generating the main, if not the sole, source of fiscal revenues and foreign exchange earnings. Studies, however, indicate that most of the countries have been unable to effectively use the resources from extractive industries and hence, are characterized by poor economic performance where the majority of their populations live in poverty. In fact, in many instances large extractive industries even appear to have retarded economic and social development through a number of phenomena often referred to collectively as the "resource curse". Many of the problems are related to the quality of governance (UNITR, n.d).

The governance of the extractive industries is required to substantially be improved not only to address the issue of revenue utilization and distribution of benefits, but also to address critical issues of social accountability (WB-IMF, 2004). It is quite imperative that extractive industries become mindful of the emerging social concerns and priorities of communities, governments, civil society organizations and other stakeholders.

Governance encompasses both the demand and supply sides where multiple actors from multiple sectors play different roles for a proper functioning of the governance equation. The demand-side governance initiatives refer to citizenor civil society-led activities to exact accountability from power-holders, producers and service providers. In this side of the equation, there are a number of initiatives and approaches ranging from social movements using protest, to communities negotiating and making decisions with the state, investors and service providers whose activities have a direct or indirect bearing on their environment, human rights and cultural and social values. The supply side of the governance equation refers to roles and activities of state and private investors to provide proactive measures to protect the natural environment and rights and interests of local communities (Claasen et al., 2010:4).

\section{The Concept of Social Accountability}

Social accountability is an important extra-state approach that relies on civic engagement where ordinary citizens and civil society organizations actively participate directly and indirectly in exacting accountability (Kiwekete, n.d). Social accountability can be defined as the ability to require that public officials, private investors, and service providers answer for their policies, actions, and use of funds (IBRD, 2005:1). Corporate social accountability for private business operators can be defined as "The continuing commitment by business 
to behave ethically and contribute to economic development while improving the quality of life of the workforce and their families as well as of the local community and society at large". This definition implies that any individual company has to integrate social (including human rights), environmental and economic concerns into its values and culture so that these values are reflected in that company's policies, strategies, decision-making, and operations (PDASDCSR, 2007:1).

Social accountability should promote both responsiveness and accountability of government at various stages throughout the formulation, implementation, monitoring and evaluation of government policies and programs (Caddy, et al., 2007). This entails that accountability is not merely a once-off activity but a continual process between duty-bearer (public official) and rights-holders (citizens) (Claasen et al., 2010). When such a system of accountability is successful, it improves the ability of citizens to realize their interests, protect themselves from arbitrary political powers, and to control the way in which public authorities behave in public matters (Peruzzoti \& Smulovitz, 2006).

\section{Social Accountability in the Extractive Industries}

Extractive industries are engaged in extracting nonrenewable natural resource, including oil and gas, metals, industrial minerals, coal and gemstones (Ali, et al., 2007:6). In the process of extracting, they may strip bare a piece of land and also affect other pieces of land through dumping of excess earth, as well as produce negative externalities in the form of solid waste, pollution of both air and water (ECA, 2007:25). Such activities of the extractive industries cause physically irreversible impact on topography and as well as quickly destroy the ecosystems on which humans depend. Large scale modern extractive industries have major impacts on social and cultural values of the adjacent communities. Moreover, extractive industries are exploiting publicly owned (i.e. 'social') minerals, which are raising important questions regarding distribution of economic benefits (Ali et al., 2007:26).

The activities of extractive corporations have detrimental impacts on the environment, human rights and land of the local peoples. Environmentally, local peoples are suffering from erosion of biological diversity; pollution of soil, air and water; and destruction of whole ecological systems, among others. Displacement, arbitrary arrests, detentions, and lack of rights to land, territories and resources are the most common and rampant human rights violations. The expansion of big extractive industries has also destroyed and undermined the 
livelihoods, traditions and religions of local peoples. Big transnational and national corporations usually enter into local peoples' territories with a promise of development to the local peoples by providing jobs, construction infrastructure and payment of governmental taxes. In many parts of the world, these promises have little or no impact on the lives of the local peoples and hence, they still live in a situation of dire poverty (IPICPRE, 2009).

Due to the heavy physical, environmental, social, and cultural destruction, the extractive industries are causing, as well as the human rights violations they face enormous challenges in maintaining their "social license to operate", especially in developing countries. There are pressures from different corners, which among others include appeals from the sustainable development agenda, rising expectations and demands from civil-societies, local community members, and human rights agencies (ECA, 2007:25). In light of these pressures, there are increasing interests in investigating the state of social accountability in various developing countries in which only little is known. Issues of social accountability for extractive industries can be examined among others from the view point of the three major pillars: principles of human rights, of sustainability; and of social license to operate (Ali et al., 2007:11).

\section{Principles of human rights}

Extractive corporations, like governments, have a responsibility to respect fundamental human rights in their organization and conduct of business. In this respect, key human rights principles would include the right to a clean environment; the right to land, territories and resources; the right to free prior and informed consent; and protection from involuntary resettlement (Ali, et al., 2007:12).

Environmental impacts of the extractive industries are not limited to pollution of land, air and water. They have caused destruction of the whole ecological systems, which have significantly contributed to the climate change (IITC, 2009). As a result, environmental right has received increasing attention and recognition, not only for its own sake, but also due to the fact that unless the physical environment is protected, other human rights ${ }^{2}$ may be threatened (Ali, et al., 2007:12). Hence, extractive industries are expected and required to take all the precautious measures to protect the environment and public health within

${ }^{2}$ The right to economic and social development, the right to practice culture and ultimately the most fundamental of all human rights, the right to life.

EJBE Vol. 6 No. $1 / 2016$ 
the framework of laws, regulations and administrative practices of countries in which they operate and as well as international laws (ECA, 2007:10).

Rights to lands, territories and resources are fundamental to local peoples because their economic and social development, physical and cultural integrity, and their livelihoods and sustenance greatly depend on secure, effective and collective property rights. Secure land and resource rights are also essential for their very survival as viable territorial and distinct cultural communities (TFIPICPRE, 2006). Thus, states should avoid laws and legal systems that arbitrarily declare resources that belong to local peoples. Of course, states' power to take resources for public purposes (with compensation) cannot be undermined; however, this should be exercised in a manner that fully respects and protects all the human rights of local peoples. Local peoples demanded that compensation for land and other resources should encompass not only remuneration for economic losses but also reparations for the social, cultural, environmental, and spiritual losses they endured (CEE Bankwatch Network, n.d).

Contemporary international law clearly recognizes the rights of local peoples to participate in decision making and to give or withhold their consent to activities affecting their lands, territories and resources. The state party should seek the informed consent of concerned community members prior to authorizing any mining that may threaten the environment in areas inhabited by these communities. The right to free, prior informed consent involves permanent processes of negotiation between local communities and developers, which by no means does not refer to nominal consultation; it is the right of local peoples that extends to the extent of saying 'no' to projects that they consider as injurious to their environment, social and cultural values. Under no circumstances, they should not be forcibly removed from their lands (CEE Bankwatch Network, n.d).

\section{Principles of sustainability}

Extractive industry corporations need to conduct their activities in a manner that contributes to the broader goal of sustainable development (ECA, 2007:10). The environmental damages that occur during the process of resource extraction could be catastrophic since the processes cause irreversible damage and hence, are contrary to any vision of sustainable development (Ali, et al., 2007:6). Local peoples are voicing loudly that they have suffered disproportionately from the impacts of extractive industries (IITC, 2009). They reject the myth of 'sustainable extraction' by arguing that extraction of natural resources has not 
contributed to 'sustainable development' of the local people. By destroying the environment and the ecology on which the local people depend, the extractive industries are creating and exacerbating poverty rather than contributing to poverty alleviation (CEE Bank watch Network, n.d).

Accepting principles of sustainability extends to the extent of limiting production by extractive industry corporations in order to recognize the limited capacity of the physical and social environments to carry the burdens of destructions caused by the industry. Relevant corporate policies in this regard might include refraining from extracting in protected and environmentally or socially sensitive areas and taking action (including constraints on production) to reduce greenhouse emissions and water usage (Ali, et al., 2007:13).

\section{Principles of social license to operate}

Social license to operate is a pragmatic approach to social accountability of extractive industry companies in which they have to accept the reality that they must secure and retain the support of the communities affected by their operations. The driving force in this regard is not an issue of demonstrating a commitment to human rights or environmental sustainability per se as companies are required by law to do so. Companies are rather involved in a pragmatic calculation of what is required to win the degree of community support to avoid delay or disruption to operations. The social license may ostensibly be easier to obtain from vulnerable impoverished communities and lead to subservience rather than true 'buy-in'. At times when local communities keep quiet, companies should not misinterpret that as an endorsement of the project and hence a 'social license' is granted. Communities may keep quiet if they believe that they are in a weaker position, but resentment may build over time and lead to widespread resistance once communities have the social capital to protest and take direct action (Ali, et al., 2007:13-14).

Thus, companies need to clearly and sufficiently inform and discuss with the local peoples about the pros and cons of any project. Instead of listing and dictating the benefits from extractive projects, companies should give the opportunity to local peoples to identify the priorities of their needs and the degree of benefits they expect. On the basis of consensus, extractive companies need to undertake meaningful community development activities, which are essential functions for maintaining their social license to operate (Ali, et al., 2007). 
Social Accountability in the Extractive Industries

\section{Actors of Social Accountability in the Extractive Industries}

Promoting and ensuring social accountability in the extractive industries require concerted efforts of multiple actors that among others include state actors, citizens, civil society organizations, private sector actors, and the media.

\section{State Actors}

The adoption of policies and practices that require adherence to and enforce standards of accountability and transparency is the principal means of ensuring sound management at all stages of natural resource exploitation (Bryan \& Hofmann, 2007:14).

In a democratic system of governance, the legislature is the supreme law making organ of a state and hence, provides legal and regulatory frameworks, which provide the framework for sustainable and accountable utilization of natural resources. It also plays a key role of overseeing the executive. Legislative bodies also provide the critical link between citizens and their elected governments and can serve as an agent of citizens to promote accountability and transparency (NDIIA, 2008). Legislatures that are capable of playing these roles are well placed to help mitigate the various economic, environmental, human rights, and socio-cultural risks posed by extractive industries (Bryan \& Hofmann, 2007).

In spite of such vital roles, the legislatures in many resource-rich countries and African countries in particular, face a host of challenges in fulfilling their mandates. Members of the Parliament in most African countries lack the skills and necessary information to fulfill their core functions (NDIIA, 2008). The technical complexity of the extractive industries further aggravated the capacity problem as many of the members of the parliaments have little or no knowledge about the extractive industries (Bryan \& Hofmann, 2007). A critical challenge is that legislatures are dominated by powerful executives and hence, regulatory mechanisms and legal frameworks are designed to serve the interests of the executive. In some countries, the problem is much more complicated by the fact that legislatures have personal or business ties to the extractive industry, presenting a conflict of interest in their oversight abilities (NDIIA, 2008).

\section{Citizens}

Citizens are at the center of social accountability as they are most affected by the extractive industries. In democratic systems, citizens play important roles in 
promoting and ensuring social accountability. There are several mechanisms through which citizens play their roles, which include participation in public policy making and investment decisions, participatory budgeting, public expenditure tracking, citizen monitoring of public service delivery, citizen advisory boards, and lobbying and advocacy campaigns (Kiwekete. n.d).

There are roles specific to the extractive industries, which citizens play, especially local peoples. These include negotiating and providing inputs to local Peoples' Development Plans to be executed by extractive companies; negotiating and entering into binding agreements with extractive companies and governments; and participating in environmental, social and cultural impact assessments to be carried out prior to the start of projects. The success of local communities in effectively carrying out these roles, however, greatly depends on the existence and practice of the right to free prior informed consent of peoples (CEE Bankwatch Network, n.d).

\section{Civil Society Organizations (CSOs)}

CSOs play important roles in fostering transparency and accountability of public institutions; and in efforts to fight inequality and exclusion. Their activities in this regard have transcended the public sector and are demanding companies to introduce sound reporting mechanism not only on their financial status but also on the environment and social corporate investment ${ }^{3}$.

Furthermore, CSOs are seeking opportunities to work with legislative bodies, and promote legislative participation in extractive industry initiatives. In many countries, they identify and support reform-minded legislators who can influence legislation and promote transparency and accountability by conducting investigatory and oversight activities. They also establish relationships with relevant legislative committees and brief them on developments in the extractive industries and the impacts on citizens. In such a way they reinforce the link between legislators and their constituents (Bryan \& Hofmnn, 2007:11).

Such and other roles of the CSOs, however, depend on the legal, regulatory and policy frameworks, and political, socio-cultural and economic factors of a country. There are also institutional factors on the part of CSOs themselves.

\footnotetext{
${ }^{3}$ Good governance in the extractive industry (http://www.sarwatch.org/research/195-theresearch-agenda.html?start=1
} 
Therefore, the task of promoting and achieving social accountability via CSOs needs to be located within contexts (Ahmad, 2008).

\section{Private Sector Actors}

Private companies should promote social accountability not only by way of mandatory legal obligations but also voluntarily. In recent years, there has been an explosion of voluntary initiatives intended to improve the social and environmental performance of business, which include socially-responsible investment and corporate sustainability reporting (IUCN, n.d).

Industry associations are other important organized private actors. Sectoral and general membership business associations such as industry associations, councils, chamber of commerce or other forms play important roles in creating common standards, visions and strategies for corporate social accountability. Such associations have better access and capacity to introduce and enforce best practices of sustainable development, environmental and human rights protection, industry specific standards for corporate responsibility, social development packages, etc (De Queiroz, et al., 2008:25).

\section{Media}

The 'supply side' of accountability has not been sufficient on its own to create change in the landscape of social accountability because in actual practice, government and private companies show little accountability to citizens. There are increasing calls for strengthening the 'demand side' of accountability where citizens and civil society actors demand accountability through forms of civic engagement (Claasen, et al., 2010). Experts note that dynamism and success to promote social accountability through civic engagements depend on the existence of strong and multi-channel media. Strong and professional media is needed because much of the information is available in forms that people, who are often, time and resource poor, cannot easily understand, interpret or use. Through informed critique and investigations, an independent and wellinformed media can play an important role in advancing greater social accountability from the extractive industry. While effective use of the media is vital for effective social accountability work, in many developing countries, they face several capacity constraints in terms of funds, opportunities for advancement, censorship and access to information (Claasen, et al., 2010:52). 


\section{Mechanisms of Social Accountability}

Social accountability mechanisms refer to a broad range of actions that citizens, local communities and civil society organizations can use to hold government officials, civil servants, private investors, and other stakeholders whose activities and decisions have a direct and/or an indirect impact on the rights and interests of citizens (Kiwekete, n.d). The concept of mechanisms of social accountability helps to develop a framework of how citizens demand and enforce accountability from actors affecting their affairs. Administrative rules and procedures, political forms of checks and balances, financial reporting, and auditing procedures are the first forms of accountability mechanisms (Claasen, et al., 2010:4). In their current usage however, social accountability mechanisms have applications in varied contexts. However, the common denominator is that each mechanism has to build citizen voice and create spaces for more pro-active engagement of citizens and civil society with the state and other actors. In broader context, the social accountability mechanisms include (Kiwekete, n.d; Ahmad, 2008):

- Right to information movements, citizen advisory boards and vigilance committees, public interest litigations, public hearings, citizens' charters, etc.

- Citizen participation in public policy making, participatory budgeting, public expenditure tracking, citizen monitoring of public service delivery, and lobbying.

- Public demonstrations, advocacy campaigns, investigative journalism; social audits, citizen report cards, citizen jury or people's verdict.

The International Bank for Reconstruction and Development and others have briefly discussed some of the following mechanisms (IBRD, 2005:11-15).

Social Audits- refers to the process of involving communities in scrutinizing public projects and the amounts actually spent on them. Social audits are also used to plan, manage, and measure non-financial activities of projects and to monitor both the internal and external consequences of their social and commercial operations.

Citizen Report Cards- are surveys of social services that affect the poor and give service recipients an opportunity to grade the agencies that provide the services.

Citizen Jury or People's Verdict- in this approach, residents of a given community are chosen by an oversight panel of NGOs and/or donor organizations to study an issue that will greatly affect that community. They are 
given information on the topic through different means that include talks, videos, and readings; have discussions with subject matter specialists; and deliberate all facets of the issue. Eventually they render their verdict on the issue to the community, the authorities, and the media.

Citizen Advisory Councils - this mechanism is designed mainly in efforts to make large-scale extractive industries more environmentally and socially accountable. The major conviction of this mechanism is that there is a need for establishing formalized structures to engage local communities and citizens in the oversight of those industries (IUCN, n.d).

Generally, public dialogue forums through which citizens, civil society actors and other stakeholders actively debate on the management of national extractive industries stimulates improved accountability, transparency and oversight by governments. In many African countries, however, either public dialogue forums are ineffective or public discussions about the management and the proceeds from the extractive industries are discouraged and even sometimes considered taboo. Efforts exerted by citizens and civil society actors to seek accountability and transparency from the extractive industries has encountered harsh responses from governments since such efforts are against the vested interests of powerful government officials. As a result, some of the mechanisms that have been created by governments in Africa do not practically function effectively or efficiently to promote accountability. Nevertheless, their mere creation has begun to gradually stimulate transparency in public discourse and increase civil society engagement on issues surrounding extractive industries (NDIIA, 2008).

\section{Social Accountability in Ethiopia}

7.1 Politico-administrative and Economic Changes in Ethiopia: an Overview

Ever since it assumed power in 1991, the Ethiopian Peoples' Revolutionary Democratic Front (EPRDF) has been introducing changes in the political, administrative and economic arenas. The 1995 Constitution of the Federal Democratic Republic of Ethiopia (FDRE) has laid the foundation and set out the goal of promoting democratic governance and economic development through a decentralized federal administration (Fenta, 2007; AIDMG, 2008).

In 1992, the EPRDF led Government introduced a market-based economic policy that aimed at transforming the command economy into a market economy through active and wider participation of the private sector (PSD Hub/AACCSA, 
2009a). The Government has issued and implemented a series of economic reform programs ${ }^{4}$ that have substantial implications for economic stabilization and structural adjustment (PSD Hub/AACCSA, 2009b). The economy is in a state of change and its performance is improving well. Reports of IMF and AfDB indicated that Ethiopia was the fastest growing non-oil driven African economy in 2007. Global development projections for 2009 also showed that Ethiopia would be one of the four fastest growing economies in the world (Fikremarkos, et al., 2009). In spite of consecutive double digit GDP growth, the economy has not made any major structural transformation. Agriculture is still a dominant sector that accounts an average of 45 percent of the GDP for the period 2001/022008/09 (NBE, 2009).

Since 1993, the Ethiopian Government has opened the extractive sector for local and foreign private investors. Currently, a number of junior exploration and world class extractive companies are operating for different mineral commodities. The role and share of the extractive industry in the economy is not, however, significant. Against the widely prevalent conviction of the country's rich mineral potential, the contribution of the extractive sector to the national economy has reached a maximum of six percent so far. In the coming 15 to 20 years, the Mineral Sector envisions to establish a diverse, world-class, competitive and environmentally sound private sector extractive industry that will contribute not less than 10 percent of the GDP (MM\&E, 2009). Irrespective of the size, the contributions and impacts of the sector on the socioeconomic development of the country and on poverty eradication in particular, however, depend on the legal and regulatory frameworks and practices of social accountability.

\subsection{Social Accountability in Ethiopia: an overview}

In addition to social accountability, which is broader in its scope, corporate reasonability is also new to Ethiopia, since corporate governance is generally a new phenomenon for the country. Both the legal frameworks and practices of corporate responsibility are very weak (Minga, 2008). Since recently however, business and sectoral associations have realized the need for a strong corporate governance framework and code of business ethics (PSD Hub/AACCSA, 2009a:104)

\footnotetext{
${ }^{4}$ Among others include privatization of state-owned enterprises, liberalizing the investment climate, deregulation of the domestic prices, devaluation of foreign exchange, and abolition of all export taxes and subsidies
}

EJBE Vol. 6 No. 1/2016 
The public sector is better familiar with the concept of social accountability than the private sector. There are some initiatives and practices in the context of public sector service delivery. Citizens Report Cards (CRCs) study, conducted by Poverty Action Networks of Ethiopia (PANE) and the Ethiopian Social Accountability Project (ESAP) are important initiatives to mention (GTZ Ethiopia, n.d).

In 2005, a pilot survey of CRCs was conducted, which was the first of its kind in Ethiopia. The result was made public in 2006. The study aimed at creating awareness among the wider citizens about the performance of public services, and how to hold service providers accountable for results. The survey covered water, health, sanitation, education, and agricultural extension services in four regional states of Ethiopia (Eshetu, 2006).

The study has clearly illustrated that if citizens are empowered, they have interest to actively be engaged in the process of performance assessment and in holding service providers accountable. The results of the study has attracted policy makers and implementers, service providers, media and other stakeholders having vested interest in promoting social accountability. At the macro level, the results have been used as inputs for the formulation of development plans while senior public managers have used the findings as a diagnostic tool in the process of monitoring the effectiveness of service delivery across wide array of areas. The media found the findings attractive in terms of its impact in promoting social accountability and ultimately reducing poverty. As a result, the findings have been placed on the larger public domain via different media, which is of vital importance to raise public awareness about social accountability (Eshetu, 2006).

The ESAP is the second initiative that aims at strengthening the use of social accountability approaches by citizens and civil society organizations as a means to make basic service (include sanitation, agriculture, health, and education) delivery more effective, efficient, transparent, responsive, and accountable. It also aims at engaging citizens and civil society organizations with decentralized public service providers and enhancing transparency of budget processes (Mai, et al., 2009). Enabling and energizing the civil society sector, citizens as well as the public sector is at the center of ESAP, so as to achieve its objectives of promoting social accountability throughout Ethiopia (GTZ Ethiopia, n.d). The ESAP awarded funds for 12 civil society organizations, with their partners representing a total of 50 civil society organizations operating in 80 
woredas/districts, towns, cities or sub-cities and hundreds of kebeles/village level administrations of Ethiopia (Mai, et al., 2009).

Though social accountability was new for most of stakeholders of the initiative, the project has produced significant practices, which serve as a learning initiative. The agenda of social accountability and the mechanism are being replicated and institutionalized by some civil society organizations and their partners, mostly based on existing structures and linked with ongoing programs (Mai, et al., 2009).

\subsection{Jurisdictional powers over the Extractive Industries of Ethiopia}

The types and scale of operations of the extractive industry in Ethiopia is very small, which is partly attributed to the governance problem of the sector. The limited initiatives of opening up of the sector for private investment by the Imperial regime were halted by the Derg regime. During the entire period of the Derg (19974-1991) private investment in the extractive industry was not allowed. Government institutions, with limited human, financial and technological capacity, were given the authority and responsibility to explore and develop the extractive industries of the country. Public sector monopoly has ended in 1992 when the Transitional Government of Ethiopia introduced market oriented economic policy and the sector is experiencing a governance system different from the previous regimes (MM\&E, 2009).

The power and responsibilities of managing the extractive sector and the benefits thereof fall in the jurisdictions of the Federal and regional governments. Activities such as artisanal and construction minerals extractions undertaken by domestic investors are under the regional governments' jurisdiction while the Federal Government has full authority over large scale extractive operations ${ }^{5}$. Artisanal mining refers to all non-mechanized extraction operations of gold, platinum, precious minerals, metals, slat, clay, and other similar minerals, an essentially natural nature carried out by Ethiopian individuals or group of such persons. Construction minerals extraction is limited to extraction of sand, gravel, stone (marble, granite, basalt, etc), and clay including non-metallic minerals used for construction purpose ${ }^{6}$. The law has made it clear that all mechanized and large scale extraction operations are under the Federal Government. Despite large-scale extraction and all petroleum and gas operations are under the Federal

\footnotetext{
${ }^{5}$ Proclamation No. 52/1993, Article 46(1)

${ }^{6}$ Ibid, Article 2(2 \&3)
} 
Social Accountability in the Extractive Industries

Government's jurisdiction, the Federal and regional governments jointly levy and collect taxes on incomes and as well as royalties from such operations ${ }^{7}$.

The power and responsibility of issuing and regulating licenses and administration of exploration activities are vested in the Ministry of Mines and Energy and bureaus of mines and energy for all extraction operations that fall within the jurisdictions of the Federal and regional governments respectively. However, the Ministry of Mines and Energy represents and provides overall strategies for the development of the extractive sector in the country. The Ethiopian Geological Survey, an autonomous institution under the Ministry of Mines and Energy, is responsible to undertake basic geological mapping, mineral exploration and other related geological activities, and generate basic geosciences data (MM\& E, 2009).

\subsection{Legal Regimes for Social Accountability in the Ethiopian Extractive Industries}

Since 1992, the Ethiopian Government has issued legal and regulatory frameworks, consistent with the new economic ideology of promoting private sector investment. On top of the FDRE Constitution, the following are important laws, which determine and regulate extractive operations in the country: Mining Proclamation No. 52/1993, Mining Income Tax Proclamation No. 53/1993, Council of Ministers Regulation No. 182/1994, and Transaction of Precious Minerals Proclamation No. 651/2009. Environmental laws, which help to regulate and protect environmental impacts of extractive projects, include Environmental Protection Organs Establishment Proclamation No. 295/2002, Environmental Impact Assessment Proclamation No. 299/2002 and Environmental Pollution Control Proclamation No. 300/2002.

This section is devoted to the review of the above legal and regulatory frameworks with regard to how they intend to promote and ensure issues of social accountability in the extractive industries. The sector is expected to grow fast so as to contribute its best to the overall development of the country. In light of this aspiration, it is quite imperative to assess how well informed and comprehensive the legal regimes are in addressing issues of social accountability.

${ }^{7}$ Proclamation No. 1/1995, Article 98(3)

EJBE Vol. 6 No. 1/2016 


\section{Principles of human rights}

Proclamation No. 1/1995 recognizes a whole spectrum of human rights. The Country has also ratified major international instruments that guarantee human rights (AIDMG, 2008). "All persons have the right to a clean and healthy environment." " The Constitution further reasserts that the government should work hard to ensure that all Ethiopians live in a clean and healthy environment ${ }^{9}$. To this end, the design and implementation of development programs and projects are required to be carried out in a way that does not cause any major damage or destroy the natural environment. Another law ${ }^{10}$ also states that no person shall pollute or cause any other person to pollute the environment nor a project, which has a negative environmental impact, shall commence implementation without environmental impact assessment and authorization ${ }^{11}$.

Every enterprise engaged in the extractive sector is required to conduct extraction operations in such a manner that ensures the health and safety of its agents, employees and other persons, and as well as minimizes the damage or pollution to the environment ${ }^{12}$. Against the strong provision of the Constitution that prohibits any economic activity that may cause damage or destroy the environment, the above legal provision is loose, only demanding that enterprises minimize environmental damage and pollution. The provision opens a Pandora box for subjective judgment of the degree of tolerable environmental impact. Moreover, legal provisions specific to the extractive sector seem to focus on rehabilitation instead of protecting the environment before the ecosystem is destabilized. "The holder of a small or large scale mining license shall progressively restore or reclaim the land covered by the license and, if applicable, a lease so that, prior to termination of the license, the area has been completely restored or reclaimed for beneficial future use [...]." ${ }^{13}$ Such excessive dependence on restoration and reclamation encourages an unwarranted intervention into the natural environment while such activities hardly restore the natural ecosystem to its original status.

\footnotetext{
8 Proclamation No. 1/1995, Article 44(1)

${ }^{9}$ Ibid, Article 92 (1\&\&2)

${ }^{10}$ Proclamation No. 300/2002, Article 3(1\&2)

${ }^{11}$ Proclamation No. 299/2002, Article 3

12 Proclamation No. 52/1993, Article 26(3)

${ }^{13}$ Ibid, Article 29(5)
} 
Environmental Protection agencies are fully authorized to take administrative or legal measure against any person who violates this law $^{14}$. The law states that violation of obligations by any extractive enterprises relating to health and environment shall be guilty of primary infractions ${ }^{15}$. The sanction for an act that constitutes such infraction may include an immediate revocation of the license to which the infraction is related and a fine not exceeding ${ }^{16}$ about $\$ 375^{17}$. Revocation of the license has a good deal of deterring capacity, the fine however, is so nominal to deter any act or behavior.

The FDRE Constitution guarantees to every Ethiopian citizen the right to ownership of property. "The right to ownership of rural and urban land, as well as of natural resources, is exclusively vested in the State and in the peoples of Ethiopia. Land is common property of the Nations, Nationalities and Peoples of Ethiopia and shall not be subject to sale or to other means of exchange." 18 Individuals and communities have mainly use and associated rights, which undermine citizens' right to effectively exercise property rights on their land. The law has made it clear that Government is the guardian that holds, on behalf of the People, land and other natural resources and to deploy them for their common benefits and development. ${ }^{19}$ This further undermines the bargaining power of individual citizens' and local communities' as investors principally deal with the Government, which has absolute authority to deploy land and other natural resources. Hence, the law has limitation to promote and ensure social accountability from the view point of rights to land, territories and resources.

Proclamation No. 1/1995 promises that it is Government's duty to support the growth and enrichment of cultures and traditions that are compatible with fundamental human rights and dignity ${ }^{20}$. More specifically, the Government has responsibility to protect and preserve historical and cultural legacies ${ }^{21}$. To this end, "Government may exclude any area from mining operations that is related to sites of historical, cultural or religious significance"22. The law also added that village community, burial ground and land under cultivation fall under

\footnotetext{
${ }^{14} \mathrm{Ibid}$, Article 11

${ }^{15}$ Regulation No. 182/1994, Article 37(2/b)

16 Ibid

17 Converted to USD at the rate 13.35 of that time (July 2010)

18 Proclamation No. 1/1995, Article 40 (1\&3)

${ }^{19}$ Ibid, Article 89 (5)

${ }^{20}$ Ibid, Article 91(1)

${ }^{21}$ Ibid, Article 41(9)

${ }^{22}$ Proclamation No. 52/1993, Article 6
}

EJBE Vol. 6 No. 1/2016 
prohibited areas for the operation of extractive industries. Nonetheless, the law gives discretion to the licensing Authority to decide otherwise instead of completely banning extractive operations in these $\operatorname{sites}^{23}$. At the time that prohibition is accepted, the law requires mining operations only to be 100 meters away from such sites ${ }^{24}$. Due to heavy operations, such a distance is not enough to avoid negative impacts of extractive industries on physical, social and cultural assets of the local community.

In terms of peoples' rights to participate in decision making and to give or withhold their free consent to activities affecting their lives, the law states that "Nationals have the right to participate in national development and, in particular, to be consulted with respect to polices and projects affecting their community." ${ }^{25}$ The law requires that before securing license for mining operations, registration of each application should be followed by a notice that has to be published on newspapers which have wider circulation. ${ }^{26}$ On the basis of this notice, any person can file a written objection at the office of licensing authority within thirty days. ${ }^{27}$ However, the right to free prior informed consent involves permanent processes of negotiation between local communities and developers. The law does not require this; instead, it empowers the applicant to delimit the area for which the application is sought prior to application without the consents of legitimate occupants. ${ }^{28}$ Moreover, the legal provisions, lack appropriate mechanisms of informing the local people on whose land and territories the mining project is to be implemented. In the Ethiopian context, neither newspapers have sufficient distribution coverage nor have the rural local people the skill and culture of reading newspaper. Hence, publishing a notice on newspaper does not provide local peoples with sufficient opportunity to be well informed of such plans. At times local people have the information, the law does not authorize them to reject the proposal when they do not agree with; it is up to the Licensing Authority to decide on the objection ${ }^{29}$.

There are also legal provisions that intend to protect displacement of local people due to projects. "All persons who have been displaced or whose livelihoods have

\footnotetext{
${ }^{23}$ Régulation No. 182/1994, Article 11(2)

${ }^{24}$ Ibid, Article 11

${ }^{25}$ Proclamation No.1/1995, Article 43(2)

${ }^{26}$ Régulation No. 182/1994, Article 6(2)

${ }^{27}$ Ibid, Article 7(1)

${ }^{28}$ Ibid, Article 25 (1)

${ }^{29}$ Proclamation No.52/1993, Article 24 (2)
}

EJBE Vol. 6 No. 1/2016 
been adversely affected as a result of State programs have the right to commensurate monetary or alternative means of compensation, including relocation with adequate State assistance" ${ }^{30}$. The licensee should pay compensation to a legitimate occupant for all properties it has destroyed and/or damaged within or outside the licensed area. ${ }^{31}$ In any resettlement program, due to displacement caused by extractive and other projects, local peoples' free and informed consent and agreement with the offer must be obtained. Moreover, compensation should encompass not only remuneration for economic losses but also reparations for the social, cultural, environmental, and spiritual losses local communities endure (CEE Bankwatch Network, n.d). In this regard, the Ethiopian legal regime fails to effectively safeguard individual's possessory right on the land allotted to them.. Neither people are compensated for non-economic losses nor are their consents mandatory before eviction. The law has made it clear that compensation will be made only for properties destroyed and/or damaged by extractive operations. In case of disagreement, the licensing authority may cause displacement of legitimate occupants against their consent." ${ }^{32}$ In a situation in which individuals have only possessory right, government needs to introduce and enforce strong policies on compensation for all sorts of damages. Government has to also improve the situation for negotiation and consultation practice with individuals and communities (Darby, 2010).

\section{Principles of Sustainability}

Indigenous peoples in many parts of the world, particularly in African countries, have experienced catastrophic effects of the extractive industries (CEE Bankwatch Network, n.d). Hence, governments should provide legal protection against such practices. The FDRE Constitution states "The Peoples of Ethiopia as a whole, and each Nation, Nationality and People in Ethiopia in particular have the right to improved living standards and to sustainable development." 33 Every person who plans to implement a project that has a negative environmental impact is required to undertake an environmental impact assessment; identify the likely adverse impacts of the project; and incorporate the means of their prevention or containment. ${ }^{34}$ Large scale extractive operations fall in this

\footnotetext{
${ }^{30}$ Proclamation No.1/1995Article 44 (2)

${ }^{31}$ Ibid, Article 24 (3).

32 Proclamation No.52/1993, Article 24 (2)

${ }^{33}$ Proclamation No.1/1995, Article 43(1)

${ }^{34}$ Proclamation No. 299/2009, Article 7(1)
} 
category and hence, such projects are required to navigate through environmental impact assessment processes.

The principles of sustainability demand not only understanding, planning and mitigating the impacts but also extend to limiting extraction of the natural resources so that irreversible impacts on the natural and social environments could be minimized. Such limitations should be clearly stated by the laws governing the operations and development of the sector (Ali, et al., 2007). In this regard, the Ethiopian Mining Proclamation does not put any restriction on operations except for mineral water extraction. The law guaranteed extractive companies the right for an unlimited exploitation, which states as "The license area shall comprise all of the land within its boundaries and all sub-soil thereunder to an indefinite depth within the vertical plans passing through each boundary." 35 This is generally against the principle of sustainable development, which may cause irreversible damage on the ecosystem.

Previous discussions of the legal regimes for social accountability in the extractive industry in Ethiopia, from the view points of human rights and principles of sustainability, show that in spite of loopholes, the legal and regulatory frameworks provide reasonably sufficient provisions to promote social accountability. In addition to the provision of legal and regulatory frameworks, the Ethiopian Government has demonstrated its interest to promote social accountability of the extractive industries through an official application submitted to the Board of Extractive Industries Transparency Initiative (EITI) to join the initiative. The application was submitted in October 2009 on the basis of which EITI assigned reviewers to assess Ethiopia's pledge to join the initiative. However, in February 2010, Ethiopia's candidacy was suspended by EITI's Board, which stated that the new civil society law of Ethiopia bars civil society groups from engaging in human rights and governance issues. The report stated that these activities are limited only to local charities and societies that receive over 90 percent of their income from domestic sources. This, the Board states, restricts EITI from implementing its set of principles since its course of action requires not only an active involvement of extractive industry companies, but also other partners from wider society, including all categories of CSOs (GGPE, 2010). The Ethiopian Government has continued to negotiate with the Board to realize its membership.

${ }^{35} \mathrm{lbid}$, Article 32

EJBE Vol. 6 No. 1/2016 


\subsection{Actors of social accountability in Ethiopia}

Review of the general social accountability practices and the legal regimes in the extractive industries show that state, private sector, citizens and civil society organizations participate directly and indirectly in promoting social accountability in Ethiopia.

\section{State Actors}

The power of enacting laws is vested in the House of Peoples' Representatives (HPRs) and accordingly the House has been enacting laws, which govern the utilization and conservation of land and other natural resources. ${ }^{36}$ Oversight of the executive is another major function of the HPRs. Studies show that though improving, the House does not effectively carry out oversight function due to capacity problems and lack of sufficient independence. Most members of the legislature lack knowledge of standard operating procedures on legislative oversight, and duties and responsibilities of the executive (Paulos, 2007). A more serious concern is, however, the dominance of the Executive over the Legislature (AfDB, 2009:5). Critics assert that the Ethiopian Legislature is dominated by a powerful ruling party-EPRDF and hence, has few real powers to effectively check on the executive (Nyang, 2009).

The Council of Ministers has a power to enact regulations and to formulate and implement economic, social and development polices and strategies. On the basis of this power, it has provided with the Mining Regulation that consists of several important provisions towards social accountability. ${ }^{37}$ Though law making with regard to land and natural resources utilization is the prerogative of the Federal Government, regional States have been given the power to administer land and other natural resources in accordance with Federal laws ${ }^{38}$. Hence, they are important actors to promote and enforce social accountability in their jurisdictions.

The Ministry of Mining and Energy (MM\&E), and the Environmental Protection Authority are the two most important Federal institutions engaged in the management of natural resources and protection of the environment respectively. The MM\&E is specifically responsible for issuing license and

\footnotetext{
${ }^{36}$ Proclamation No. 1/1995, Article 55(2/a)

${ }^{37} \mathrm{Ibid}$, Article $77(1,6$ \&13)

${ }^{38} \mathrm{Ibid}$, Article 52(d)
} 
inspecting activities of large scale extractive operations so as to ensure that operations are carried out in accordance with the law. ${ }^{39}$ It is fully empowered to license and revoke whenever a licensee fails to observe and meet legal requirements. The Ministry is also responsible for determining compensation for properties when the licensee and legitimate occupants fail to agree with the amount. ${ }^{40}$ Regional mining and energy bureaus have the responsibility and authority to exercise similar functions with that of the Ministry with regard to artisanal and construction mining. ${ }^{41}$

The Environmental Protection Authority has been assigned the major responsibly of coordinating environmental protection activities and measures to ensure that the environmental objectives provided under the Constitution are realized. The Authority is empowered to formulate policies, strategies, laws and standards that foster social and economic development in a manner that enhances the welfare of humans and the safety of the environment for sustainable use. ${ }^{42}$ The Authority has identified and provided standards for projects that strictly require environmental impact assessment before commencing implementation, among which large scale extractive operation is one. The environmental impact assessment report of any project is subject to review by the Authority or the relevant regional environmental agency. If experts' opinions and public comments demonstrate that the project has a significant negative impact, the Authority or the relevant regional environmental agency is authorized to refuse the implementation of the project ${ }^{43}$. The law also authorizes the Authority and regional environmental agencies to monitor implementation of authorized projects in order to ensure that they comply with their obligations as stated by the law. All these provisions stand for and demand social accountability from extractive companies.

\section{Citizens}

The mining and environmental legal frameworks of Ethiopia have provided certain provisions that create opportunities for citizens to participate in decision making and investment that has potential negative impacts to their interests. Federal and regional environmental protection agencies are required by law to

\footnotetext{
39 Proclamation No. 52/1993, Article 46(2/d)

${ }^{40}$ Ibid, Article 24(2)

${ }^{41} \mathrm{Ibid}$, Article 46

${ }^{42}$ Proclamation No. 295/2002, Articles $5 \& 6$

${ }^{43} \mathrm{lbid}$, Article 9(2)
} 
seek public comments while reviewing projects' environmental impact assessment ${ }^{44}$. The laws, however, do not give the power to the community to reject a project, which they believe in that it is totally against their interests. Such powers are discretionary powers of the Authority or the relevant regional environmental agency. Citizens are authorized to lodge a complaint at the environmental agencies against any person allegedly causing actual or potential damage to the environment ${ }^{45}$. In this case, the law provides the person who lodged the complaint the opportunity to instate a court case if the environmental agencies fail to give decision within thirty days or when the person is dissatisfied with the decision.

Local peoples have the right to directly negotiate about the amount of compensation with any licensee whose investment in mining operation causes displacement ${ }^{46}$. This is an important provision that provides space for the local people to play role in social accountability of the extractive industry. Nonetheless, the legal provision does not fully authorize citizens to say no for reasons they do not agree with the amount of compensation. It is up to the environmental protection agencies to decide on the disagreement.

Citizens' participation in extractive operations is not limited to a situation that involves displacement of legitimate occupants. Though local peoples have limited access to required information, any person can file a written objection to the grant of any kind of license for mining operation at the Ministry of Mines and Energy or the relevant regional mining and energy bureau. ${ }^{47}$ In spite of the limitation of access to information, this creates an avenue for local people to participate in investment decision.

\section{Private sector actors}

Social accountability is generally new to the private sector in Ethiopia. As a result, self-initiated and organized effort of the private sector to promote social accountability is negligible. In fact, the private sector is blamed for its excessive inclination towards corruption instead of promoting transparency and accountability. Private business officials hardly differentiate what they call an acceptable marketing scheme and clear-cut corruption (Kebour, n.d). The private

\footnotetext{
${ }^{44}$ Proclamation No. 299/2002, Article 9(2)

45 Proclamation No. 300/2009, Article 11

${ }^{46}$ Proclamation No. 52/1993, Article 24(2)

${ }^{47}$ Regulation No. 182/1994, Article 7
} 
sector seems to have resigned corrupt practices as a necessary cost of doing business (Hayal, 2008).

The law, however, has assigned important roles and responsibilities to investors, which are significant to promote and ensure social accountability in the extractive industry. Each project owner is required to conduct environmental impact assessment. The project owner in his/her environmental impact assessment report should clearly identify the likely adverse (direct and indirect) impacts of his/her project and as well as incorporate the means of their prevention or containment. ${ }^{48}$ If the intended extractive operation involves displacement, the project owner has to directly negotiate with legitimate occupants to determine the amount of compensation to be paid to the occupants in return to the loss of their properties ${ }^{49}$. In terms of contribution to the local development activities, though not mandatory, the law states that the Licensing Authority may require the licensee to cooperate and contribute financially in the construction and maintenance of infrastructure within the areas covered by the license or lease ${ }^{50}$. The development of such infrastructure is limited within the areas of the license and lease, hence, it cannot in strict sense be considered as contribution to the local development. The local people can benefit little since they have restricted access to the areas covered by the license and lease.

\section{Civil society organizations and the media}

The Ethiopian Government believes that civil society organizations are important actors in the socio-economic development endeavors (AIDMG, 2008). In spite of this, there are several criticisms against the new (2009) civil society law enacted by the Ethiopian Government. The new law is considered as having serious impact on civil society organizations engaged in advocacy and human rights.

Reviews of principal laws of the extractive industries in Ethiopia revealed that the roles and responsibilities of civil society organizations and the media have not been addressed. Nonetheless, it is difficult to conclude that civil society organizations and the media have no role in promoting social accountability in Ethiopia. Though limited to public sector service delivery, different initiatives are undergoing towards building social accountability systems through donor-

\footnotetext{
${ }^{48}$ Proclamation No. 299/2002, Article 7(1)

${ }^{49}$ Proclamation No. 52/1993, Article 24(2)

${ }^{50} \mathrm{Ibid}$, Article 25(3)
} 
civil society-government partnerships. The Ethiopian Social Accountability Project (ESAP) and PANE's Citizens Report Cards are interesting initiatives in which citizens are at the centre of promoting and ensuring social accountability. The media is also playing a major role of publicizing the methods and results achieved.

\subsection{Mechanisms of Social Accountability in Ethiopia}

On top of strong legal and regulatory frameworks, social audits, citizen report card, citizen jury or people's verdict, and citizen advisory councils are the most popular mechanisms of promoting social accountability. In fact, such mechanisms have meaningful and sustainable impacts only when they have a legal basis. Of course, legally recognized mechanisms are not sufficient to promote social accountability in the extractive industries since the principle of social license to operate does not much depend on legal issues, but on the capacity and commitment of companies to sufficiently engage local people.

Despite the initiatives discussed above, so far, the most predominant mechanisms of enforcing social accountability in the extractive industries in Ethiopia is seeking compliance with the laws through inspections carried out by inspectors assigned by the Ministry of Mining and Energy, and the Environmental Protection Authority. This study however, has not assessed the extent and effectiveness of the legal and regulatory mechanisms to promote and ensure social accountability on the ground. Such assessments require empirical investigations.

\section{Conclusion}

Let alone applications, the concept of social accountability is pretty new to Ethiopia in general and to the private sector in particular. In fact, the Ethiopian private sector is less familiar not only with social accountability but also with issues of corporate governance in general.

Issues and concerns of social accountability constitute important components of human rights. In light of this, the legal regimes for the extractive industry in Ethiopia have provided basic legal and regulatory frameworks for social accountability. Nonetheless, most of the legal and regulatory provisions are not sufficient to fully promote and ensure social accountability. 
Effective social accountability depends on the proper functioning of the supply and demand sides. Provision of legal and regulatory frameworks by government to govern decisions and actions of implementing government agencies and private sector actors is not enough. There should be demand from citizens in general and the local people in particular where projects are implemented. Citizens however, should be empowered to demand and defend their rights. Citizens' are empowered when they have sufficient information about their legal rights and are allowed to exercise according to the laws. There is a need for rigorous awareness raising efforts about the legal and regulatory frameworks of the extractive industries so that citizens will be able to clearly understand their legal rights and defend against any intrusion. The reviews of the legal regimes for the extractive industries in Ethiopia show that the laws have identified neither sufficient mechanisms nor actors to keep citizens informed. The media and civil society actors play important roles in creating awareness and keeping citizens informed of their rights. The laws however, are silent in this regard. The laws should be revised to acknowledge and clearly define the roles of such actors.

Important lessons can be drawn from the social accountability initiatives in public service delivery, which include Citizens Reports Cards of PANE and the ESAP. State, private and civil society actors should join hands to replicate the experience to promote social accountability in the extractive industries. The state should create an enabling environment for other actors to operate. Civil society actors are at the centre of social accountability agendas in any sector, but their roles depend on the enabling environment and their capacity. They have to be encouraged to take part in human rights and advocacy. The role of the private sector should go beyond participation of individual companies; organized private associations, such as Chamber of Commerce and Sectoral Associations, should play an active role. Of course, donors' financial support is so crucial to scale up the initiatives.

The current legal and regulatory frameworks for the extractive industries, however, do not spell out organized public oversight structures and forums beyond government. Hence, this would undermine multi-stakeholder forums for social accountability in the extractive industry unless revisions are made.

Finally, as indicated in the introduction, this research is limited to desk reviews; the application of the laws on the ground and effectiveness of enforcement mechanisms when such laws are violated have not been examined. Hence, it is quite imperative to undertake rigorous empirical study so that the practice of social accountability in the extractive industries of Ethiopia can be examined. 
Social Accountability in the Extractive Industries

\section{References}

Ackerman, J.M. 2005. Human Rights and Social Accountability. SOCIAL DEVELOPMENT PAPERS Participation and Civic Engagement Paper No. 86. Washington, DC: The World Bank.

Claasen, M., et al. (eds.). 2010. Social Accountability in Africa: Practitioners' Experiences and Lessons. Cape Town: ABC Press.

African Institute of Management, Development and Governance (AIMDG). 2008. Ethiopia- Country Self-Assessment Report Submitted to the Governing Council of the National African Peer Review Mechanism. .

Ahmad, R. 2008. Governance, Social Accountability and the Civil Society, JOAAG, Vol. 3, No.1.

Ali, H., et al. 2007. "Introduction", in Greener Management International Issue 52, pp.1-16, 2007.

Indigenous Peoples' International Centre for Policy Research and Education (IPICPRE). 2009. "Concept Paper". International Conference on Indigenous Peoples and Extractive Industries, March 23-35, 2009, the Legend Villas, Metro Manila, Philippines.

Bryan, S. and B. Hofmann (eds.). 2007. Transparency and Accountability in Africa's Extractive Industries: the Role of the Legislature. Washington, DC: The National Democratic Institute for International Affairs.

Caddy, J., et al. 2007. Beyond Public Scrutiny: Stocktaking of Social Accountability in OECD Countries. Washington, DC: The World Bank.

CEE Bankwatch Network (n.d) 'Indigenous Peoples' Declaration on Extractive Industries'. Retrieved June 12, 2010 from http://bankwatch.org/documents/decl_wbeir_ip_04_03.pdf

Darby, S. 2010. Natural Resource Governance New Frontiers in Transparency and Accountability. London: Open Society Foundation.

De Queiroz, J.S. et al. 2008. 'Partnering With Extractive Industries for the Conservation of Biodiversity in Africa: A Guide for USAID Engagement. Retrieved June 15, 2010 from http://pdf.usaid.gov/pdf_docs/Pnadn726.pdf.

Economic Commission for Africa (ECA). 2007. 'An Overview of Corporate Governance and Accountability in Southern Africa'. Retrieved June 6, 2010 from http://repository.uneca.org/handle/10855/14957.

Eshetu $\mathrm{B}^{51}$. 2006. 'Enhancing Social Accountability through Community Empowerment to Facilitate PASDEP/PRSP implementation: The Case

${ }^{51}$ Author names without comma are Ethiopian names

EJBE Vol. 6 No. 1/2016 
Social Accountability in the Extractive Industries

of Citizen Report Cards in Ethiopia'. A paper Presented at HDCA 2006 Annual Meeting, Addis Ababa.

Fenta M. 2007. Beyond the Public Realm: Local Governance Network and Service Delivery in the Amhara and Tigray Regions, Ethiopia. Maastricht: Shaker Publishing.

Fikremarkos M. et al. 2009. Review of the Legal and Institutional Framework for Market Competition in Ethiopia. Addis Ababa: Private sector Development Hub/ Addis Ababa Chamber of Commerce \& Sectoral Associations (PSD Hub/AACCSA).

Global Geopolitics and Political Economy (GGPE). 2010. 'FINANCE: SelfPolicing of Extractive Industries a "Dismal" Failure'. Retrieved June 13, 2010 from http://globalgeopolitics.net/wordpress/2010/03/09/financeself-policing-of-extractive-industries-a-dismal-failure/

GTZ Ethiopia. n.d. 'Protection of Basic Services (PBS) - Ethiopian Social Accountability Project'. Retrieved June 10, 2010 from http://www.gtz.de/en/weltweit/afrika/aethiopien/23596.htm

Hayal A. 2008. 'The perception of Corruption and its Unique Features in Ethiopia'. The Reporter (Ethiopia), 04 October 2008.

International Union for Conservation of Nature (IUCN). n.d. 'Theme on the Social and Environmental Accountability of the Private Sector (SEAPRISE)' . Retrieved May 20, 2010 from

http://www.iucn.org/about/union/commissions/ceesp/wg/seaprise/\#extr active

Kebour G. n.d. 'Dealing with Corruption in Ethiopia.' Retrieved June 16, 2010 from http://www.devoutreach.com/september06/SpecialReport/tabid/1637/ef ault.aspx.

Kiwekete, H.M. n.d. 'Social Accountability (SA8000): The Standard for the Present and the Future'. Retrieved June 6, 2010 from http://web.worldbank.org/WBSITE/EXTERNAL/TOPICS/EXTSOCIA LDEVELOPMENT/EXTPCENG/0, contentMDK:20509424 menuPK: 1278120 pagePK:148956 piPK:216618 theSitePK:410306,00.html.

Mai, G., et al. 2009. Piloting Social Accountability in Ethiopia Analytical Report with Case Studies. Addis Ababa: GTZ International Services.

Minga N. 2008. 'Rethinking Corporate Governance in Ethiopia.' Retrieved June 8,2010 from http://papers.ssrn.com/sol3/papers.cfm?abstract_id=1264697.

Ministry of Mines and Energy, Federal Democratic Republic of Ethiopia .2009. 'National Report on Mining to the United Nation Commission on 
Social Accountability in the Extractive Industries

Sustainable Development (UNCSD)'. Addis Ababa: Ministry of Mines and Energy, Federal Democratic Republic of Ethiopia

National Bank of Ethiopia (NBE). 2009. National Bank of Ethiopia Quarterly Bulletin, V. 24, No.4 Fourth Quarter, 2008/09 Fiscal Year Series. Addis Ababa: NBE.

National Democratic Institute for International Affairs (NDIIA). 2008. 'Promoting Transparency and Accountability of Revenue of the Extractive Industries: A Meeting for Legislators of the East African Legislative Assembly', February 27 - 29, 2008. Retrieved June 12, 2010 from

http://www.ndi.org/files/2317_sea_ealaworkshop_engpdf_02292008.p df .

Nyang, M. 2009. "The Dominant Executive in Ethiopia” . SUDAN TRIBUNPlural News Views on Sudan, 24 November 2009. Retrieved June 9, 2010 from http://www.anyuakmedia.com/com_temp_09_11_25.html.

Paulos C. 2007. What One Hand Giveth, the Other Hand Taketh Away: Ethiopia's post- 1991 decentralization reform under neopatrimonialism. Maastricht: Shaker Publishing.

Peruzzoti, E and C. Smulovitz. 2006. 'Review of: Enforcing the Rule of Law: Social Accountability in the New Latin American Democracies', in Ram, U. (ed.) Political Review Net First For Politics and International Relations Book Reviews.

Private Sector Development Hub/Addis Ababa Chamber of Commerce and Sectoral Associations (PSD Hub/AACCSA). 2009a. The Road to Private Sector development Led Economic Growth: a Strategy Document. Addis Ababa: PSD Hub/AACCSA.

PSD Hub/AACCSA. 2009b. Review of the Legal and Institutional Framework for Market Competition in Ethiopia. Addis Ababa: PSD Hub/AACCSA.

Prospectors and Developers Association of Sustainable Development and Corporate Social Responsibility (PDASDCSR). 2007. 'Tools, Codes and Standards for the Mineral Exploitation Industry Canada (A Special Publication)'. Retrieved June 6, 2010 from http://www.pdac.ca/docs/default-source/public-affairs/csr-sustainabledevelopment.pdf?sfvrsn $=8$

Schloss, M., et al. 2007. 'Governance Framework for Extractive Industries in Africa - Mining Guidelines for Governance Work Volume I'. Retrieved June 11, 2010 from www.sur-invest.com/.../BankNetherland\%20Partnership\%20Program\%20(BNPP\%20... 
Social Accountability in the Extractive Industries

Tebtebba Foundation Indigenous Peoples' International Centre for Policy Research and Education (TIPICPRE). 2006. 'Indigenous Peoples' Rights, Extractive Industries and Transnational and Other Business Enterprises: A Submission to the Special Representative of the Secretary- General on human rights and transnational corporations and other business enterprises', 29 December 2006. Retrieved May 27, 2010 from

http://www.google.com.et/\#hl=en\&\&sa=X\&ei=4yUXTNTmN5X44ga

Tt4j3Cw\&ved=0CBAQBSgA\&q=Indigenous+peoples\%27+rights, +ext ractive+industries+and+transnational+and+other+business+enterprises $\&$ spell $=1 \& \mathrm{fp}=13 \mathrm{f} 5 \mathrm{~d} 39 \mathrm{a} 0 \mathrm{c} 3 \mathrm{ac} 61 \mathrm{c}$.

The International Bank for Reconstruction and Development (IBRD). 2005. Stocktaking of Social Accountability Initiatives in the Asia and Pacific Region. Washington, DC: The World Bank.

The International Indian Treaty Council (IITC). 2009. 'The Manila Declaration of the International Conference on Extractive Industries and Indigenous Peoples'. Retrieved June 9, 2010 from http://www.treatycouncil.org/PDFs/The\%20Manila\%20Declaration\%2 0\%20Final \%20Version.pdf.

United Nations Institute for Training and Research (UNITR). n.d 'Governance of Extractive Industries'. Retrieved June 9, 2010 from http://www.unitar.org/event/governance-extractive-industries.

World Bank. 2007. 'Ethiopia Accelerating Equitable Growth Country Economic Memorandum, Part II: Thematic Chapters'. Retrieved June 12, 2010 from https://openknowledge.worldbank.org/handle/10986/7866.

World Bank- International Monetary Fund (WB-IMF). 2004. 'Spring Meetings: Civil Society Sessions Meting on the Extractive Industries Review', April 22. Retrieved May 20, 2010 from http://www.ifc.org/ifcext/eir.nsf/Content/WBGCivilSocietyMeetingTra $\underline{\text { nscript }}$

\section{Legislations}

Transitional Government of Ethiopia (TGE) Council of Ministers Regulation No. 182/1994, Council of Ministers Regulations on Mining Operations, Negarit Gazeta of the the Transitional Government of Ethiopia, 53rd Year No.84.

TGE Proclamation No. 52/1993, a Proclamation to Promote the Development of Mineral Resources, Negarit Gazeta of the Transitional Government of Ethiopia, 52 ${ }^{\text {nd }}$ Year No. 42. 
Federal Democratic Republic of Ethiopia (FDRE) Proclamation No. 1/1995, A Proclamation to Pronounce the Coming into Effect of the Constitution of the Federal Democratic Republic of Ethiopia, Federal Negarit Gazeta of the Federal Democratic Republic Ethiopia, $1^{\text {st }}$ Year No.1.

FDRE Proclamation No.295/2002, Environmental Protection Organs Establishment Proclamation, Federal Negarit Gazeta of the Federal Democratic Ethiopia, $9^{\text {th }}$ Year No.7.

FDRE Proclamation No. 299/2002, Environmental Impact Assessment, Federal Negarit Gazeta of the Federal Democratic Republic Ethiopia, $9^{\text {th }}$ Year No.11.

FDRE Proclamation No. 300/2002, Environmental Pollution Control Proclamation, Federal Negarit Gazeta of the Federal Democratic Republic Ethiopia, ${ }^{\text {th }}$ Year No. 12. 